\title{
Processing National Examination Result for Junior High School, Senior High School and Vocational School in Indonesia
}

\author{
Giri Sarana Hamiseno*, Handaru Catu Bagus, Fahmi, Rahmah Zulaiha, Haryo Susetiyo, Abdul Rahman \\ Centre for Assessment and learning, Research and Development and Books Agency \\ MOEC \\ Jakarta Pusat, Indonesia \\ *giri.sarana@kemdikbud.go.id, handaru.catu@kemdikbud.go.id, ffahmi6@gmail.com,rahmahzulaiha@gmail.com, \\ susetiyoharyo@gmail.com,rahman.abdul@kemdikbud.go.id
}

\begin{abstract}
The aim of development an application called Analisis Data Laporan Asesmen Nasional (ANDALAN) is to assist the data processing of the National Examination (UN) results. The amount of raw data from the $U N$ results of junior high school, senior high school and vocational school level from all regions in Indonesia every year reaches \pm 7.5 million participants. There are two types of reports of the $U N$ results data processing, namely data processing for students' UN scores and national report for $U N$ results. The raw data needs to be processed as quickly as possible, because the UN results in the form of scores will be used for admission of new students whose time is very close each other. The report structure of UN scores and UN results consists of variables such as provinces, districts/cities, levels of education, school names, subjects, exam types, status of education units, and national exam achievements, average national exam scores, the average UN score per district/city, the average UN score per school, the absorption of UN material, the comparison of $U N$ results between years. Reports of students' UN scores is submitted to the provincial education office, district/city education office and schools. Reports of $\mathrm{UN}$ results in national scale is issued by the Ministry of Education and Culture and can be accessed via the web https://hasilun.puspendik.kemdikbud.go.id. The features displayed on the webpage contain information on the achievements of the National Examination presented in graphical form, containing an overview of the UN each year, general statistics and grades distribution, percentage of students answering correctly (absorption of material), comparison of the average scores of each region and education unit, UN release questions, regional infographics, and spatial data on UN results. From the application development design, the ANDALAN application was found to function very well in processing UN results data both in the form of students' $U N$ scores and in the form of $\mathrm{UN}$ results in national scale. This application continues to be developed and adapted to the needs of both UN data processing and other interests such as research or surveys.
\end{abstract}

Keywords-national examination result, senior high school, vocational high school

\section{INTRODUCTION}

Education is an effort to make quality human resources. A nation with good and quality human resources is the hope and dream of a country that will bring it to independence, prosperity, and be able to compete with other nations in the world. Good quality of human resources can only be built with a planned and systematic effort through quality education. In the 21 st century, human resources are required to be able to master various skills that are essential in facing various problems and challenges. 21 st century skills can be categorized as (1) ways of thinking, (2) skills to take action and communication skills (ways of working and communication), (3) skills to use supporting components (tools for working), (4) literacy and mastery of information technology/information communication technologies (ICT), and (5) skills related to awareness as a world citizen (skills for living in the world [1]. The order of competence in the 21 st century according to the business world/industry is: (1) critical thinking and problems solving; (2) communication and collaboration, and (3) creativity and innovation [2].

The efforts to improve the quality of education require time and support from all stakeholders so that education runs well. Therefore, although the results are still far from the expectation, the improvement of the quality of Indonesian education is still being carried out, especially in the teaching and learning process in the classroom. Learning is defined as a process of behaviour change as the interaction of students with their environment, while studying is a process of interaction between students and educators in a learning environment. Between studying and learning are two concepts that are interrelated and cannot be separated. Both are the main activities in education. Learning is a conscious effort from an educator to teach his students (directing student interaction with other learning sources) in order to achieve the goal [3].

In order to control the quality of education outcomes in accordance with national education standards, the government needs to set assessment standards. This standard regulates the 
assessment of learning outcomes by educators, by educational units and by the government. Furthermore, it is explained that the assessment of learning outcomes by the government is carried out in the form of a National Examination (UN) starting from the junior high school, high school and vocational school levels. The National Examination is a standardized test conducted by the government, the Ministry of Education and Culture, to measure student achievement on a national scale [4]. Based on the results of the national examination, the government can identify if there are differences in the achievements of each province, district/city, even in the school level. Furthermore, the results of the identification can be a reference for the government to suppress these differences in achievement and improve the quality of education.

The preparation of the UN package for each test subject comes from the same grid. The UN grid is prepared based on the criteria for achieving competency of graduates, content standards, and based on cognitive level and material scope [58]. The test packages used in the UN are assembled from the PUSMENJAR items bank. The items have been calibrated and each item is on the same scale. Test is a systematic procedure used to obtain information about the abilities possessed by the test takers [9-11]. According to Brennan [12], test validity is the ability of a test to measure according to what you want to measure, while test reliability refers to the consistency of measurement results. Reliability is the degree of consistency of twice the measurement results on the same object [13]. Meanwhile, according to Anastasi and Urbana [14], test reliability is the stability of the score obtained by the same person when they are retested with the same test at different times or with different sets of equivalent questions, or at different measurement conditions. A test that is considered to be a good test must meet both of these requirements, so that the test is able to provide an actual picture of the condition of the testee being tested. In other words, the test packages used in the UN are valid and reliable, in addition to this, each item in a different test package must be parallel in terms of the material and abilities being tested. It is expected that the average level of difficulty for each test package is relatively the same. According to Indriana et al [15], these parallel questions can be obtained with an Automatic Item Generation Machine.

The implementation of the UN in the 2018/2019 academic year was carried out on a computer basis (UNBK), but in some areas it still uses paper and pencil-based UN (UNKP). UNKP implementation in several areas is constrained by availability of computer equipment, especially electricity and internet networks. Computer-Based National Examination (UNBK), also known as Computer Based Test (CBT), is a system for implementing the national exam using a computer as the test medium. In its implementation, UNBK is different from the paper-based national examination system (PBT) which has been running so far. The first UNBK was held online in 2014 and was limited to SMP Indonesia Singapore and SMP Indonesia Kuala Lumpur (SIKL). The results at the two schools were quite delighting and were increasingly encouraging to increase student literacy towards ICT (Information and
Communication Technology). The number of UNBK participants from 2015 to 2019 can be seen in table 1 below.

TABLE I. NUMBER OF PARTICIPANTS IN THE NATIONAL EXAMINATION AT SMP, SMA, AND VOCATIONAL HIGH SCHOOLS DURING THE LAST FIVE ACADEMIC YEARS USING THE UNBK MODE

\begin{tabular}{|l|l|l|l|l|}
\hline \multirow{2}{*}{$\begin{array}{c}\text { Academic } \\
\text { Year }\end{array}$} & \multirow{2}{*}{ Participant } & \multicolumn{3}{|c|}{ School Number } \\
\cline { 3 - 5 } & & SMP/MTS & $\begin{array}{c}\text { SMA/MA/ } \\
\text { SMTK/SMAK }\end{array}$ & SMK \\
\hline $2014 / 2015$ & 170.578 & 42 & 135 & 379 \\
\hline $2015 / 2016$ & 922.447 & 984 & 1.298 & 2.100 \\
\hline $2016 / 2017$ & 3.659 .696 & 11.096 & 9.652 & 9.829 \\
\hline $2017 / 2018$ & 5.967 .237 & 28.620 & 18.346 & 12.499 \\
\hline $2018 / 2019$ & 7.072 .442 & 43.834 & 20.900 & 13.305 \\
\hline
\end{tabular}

Source: Puspendik, Report on National Examination Results for SMP / MTS, SMA / MA, and SMK from Years 2014/2015 Academic Year to 2018/2019 Academic Year in UNBK Mode

From Table 1, it can be seen that in 2015 a pilot UNBK was carried out by including 556 schools and this also shows that most of the UN is carried out on a paper and pencil basis (UNKP). In 2019, almost all schools in Indonesia used UNBK with around \pm 7.5 million students. With a large number of UN participants required technology in the form of applications that can process the UN result data accurately in a short time.

\section{PROBLEMS}

In 2019, almost all schools in Indonesia used UNBK with a total number of participants of around \pm 7.5 million students and the subjects tested were very diverse. With a large number of UN participants and various types of subjects, technology is needed in the form of an application that can process the UN result data accurately in a short time.

\section{PURPOSE}

The purpose of developing the application for the National Examination Data Processing System (SPDUN) is to help process data on the results of the National Examination (UN).

\section{ANDALAN APPLICATION}

Analisis Data Laporan Asesmen Nasional (ANDALAN) is an application designed to assist the processing of data on the results of the National Examination (UN) using technology. Web-based applications run by using a computer and an internet connection $[16,17]$. The number of raw data from the UN for SMP, SMA and SMK from all regions of Indonesia reaches \pm 7.5 million participants each year. The raw data needs to be processed as quickly as possible, because the UN results in the form of grades will be used for admission of new students whose time is very short. There are two types of reports from the results of UN data processing, namely data processing for student UN scores and national UN reporting. The structure of reporting student UN scores and reporting UN results consists of variables such as province, district/city, level of education, school name, subject, exam model, status of educational units, and national exam results, average UN scores Nationally, the average UN score per district/city, the average UN score for schools, the absorption of UN materials, 
the comparison of the UN results between years. The report of student national examination scores is submitted to the provincial education office, district/city education office and schools. These report on the results of the National Examination, both student scores and national reports are issued by the Ministry of Education and Culture can be accessed via website https://hasilun.puspendik.kemdikbud.go.id. The features displayed on the website display information on the achievement of the National Examination presented in graphical form, containing an overview of the National Examination each year, general statistics and value distribution, the percentage of students who answered correctly (material absorption), the comparison of the average score of each region and educational units, released questions, regional infographics, and spatial data from the UN results.

\section{REPORTING OF RESULTS}

There are two types of reports that must be presented, namely: student UN scores and national UN results reports. The following is an explanation of the two types of reports.

\section{A. Students' UN Scores}

There are two types of reports that must be presented which are processed from raw data on UN results, namely: student UN scores and national UN results reports. The structure and appearance of the student UN scores are presented in the following figure 1 .

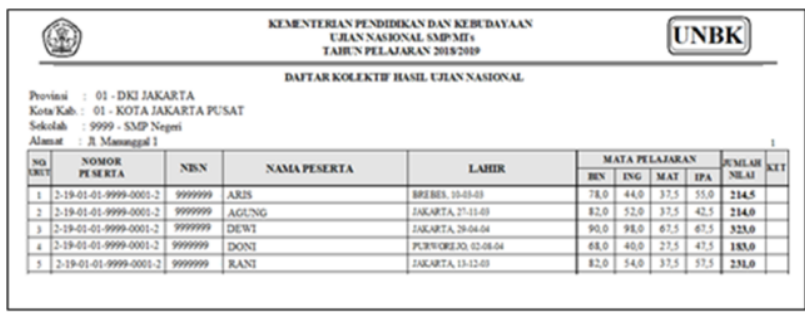

Fig. 1. SMP/MTs national exam values for the 2018/2019 academic year.

The classification of National Examination (UN) scores according to the Ministry of Education and Culture (2016) is divided into four categories, namely: a) Very Good: A (average UN score> 85.0); b) Good: B (70.0 <average UN score $\leq 85.0)$; c) Moderate: C (55.0 <average UN score 70.0); d) Deficient: D (average UN score $\leq 55.0$ ).

\section{B. National UN Results Reports}

The report on the results of the National Examination includes: (1) National Achievements, (2) Regional and Education Units Achievements, (3) Mastery of National Examination Materials, (4) List of Regional and Educational Units Scores, (5) Released Questions, (6) Regional Infographic, (7) National Examination Result Spatial Data, and (8) National Examination Report Card.
1) National achievements: The features contained in the National Achievement Graph include: Test Mode (All, UNBK, UNKP), academic year, level (major), and status of educational units (public, private, public and private), and graphics of average achievement scores. An example of national achievement is presented in Figure 2 below.

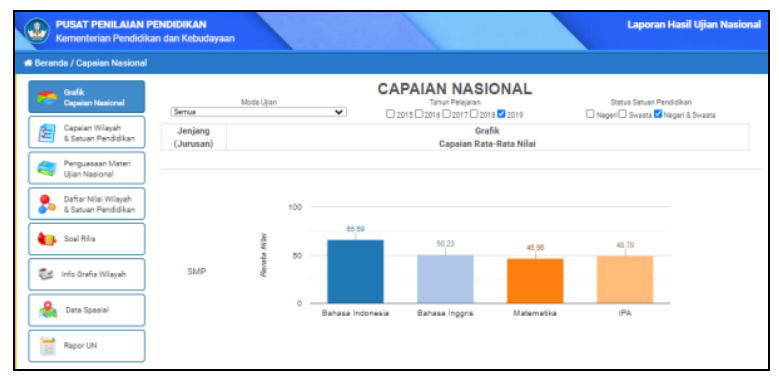

Fig. 2. Average achievement of national examinations for the 2018/2019 academic year.

From Figure 2, it can be seen the graphic of the average achievement of the national exam scores for each subject in junior high school, then if it is scrolled down, it will see a graphic of the average score achievements of MTs, SMA (Language), SMA (IPA), SMA (IPS), SMA (Catholic), SMA (Protestant), MA (Language), MA (IPA), MA (IPS), MA (Religious), SMK, Senior High School Equivalency/Paket C (IPS), and the average score of Junior High School Equivalency/Paket B.

2) Regional and education units achievements: The features contained in the national achievement chart include: level (SMP/MTs, SMA/MA, SMK, Junior High School Equivalency/Paket B, and Senior High School Equivalency/Paket C), exam mode (all, UNBK, UNKP), city/district, year, educational unit, status education unit (public, private, public and private), level, status of education unit (public, private, public and private), type of education unit, subject examination, graphic of study program, statistics, and distribution of average UN scores, and average score. An example of the UN average regional achievement display is presented in Figure 3 below.

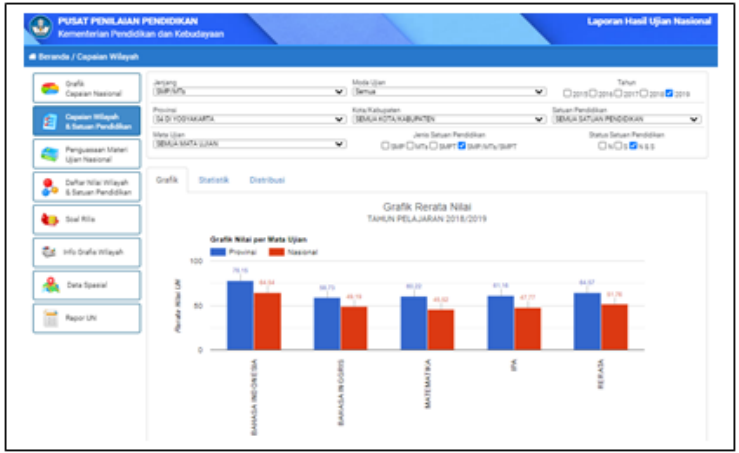

Fig. 3. Regional achievements in the national examination for SMP/MTs 2018/2019 academic year. 
From Figure 3, it can be seen that the graphic of the average national examination score achievement for each junior high school student subject. By choosing a level, it will display a graph of the average score achievement of MTs, SMA (Language), SMA (IPA), SMA (IPS), SMA (Catholic), SMA (protestant), MA (Language), MA (IPA), MA (IPS), MA (religious), SMK, Senior High School Equivalency/Paket C (IPS), and Junior High School Equivalency/Paket B.

3) Mastery of national examination materials: The features contained in mastery of UN material include: level (SMP/MTs, SMA/ MA, SMK, Junior High School Equivalency/Paket B, and Senior High School Equivalency/Paket C), exam mode (all, UNBK, UNKP), province, city/district, year, education unit, type of education unit, status of education unit (public, private, public and private), level, subject of examination, study program, material to be tested, graphics, absorption level (percent), indicators tested, and scores. An example of displaying the mastery of UN material is presented in Figure 4 below.

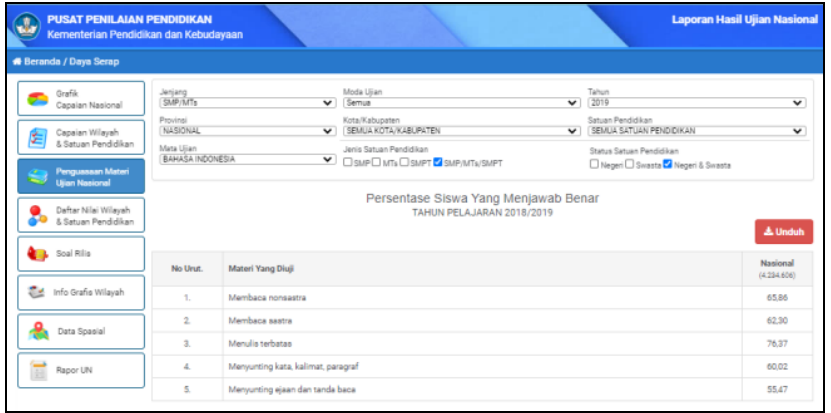

Fig. 4. Mastery of national exam material SMP / MTs for the 2018/2019 academic year.

From Figure 4, it can be seen a graphic of the mastery of the National Examination material at the SMP/MTs level. In the same way and choosing a level, it will display a graphic of material mastery for SMA (Language), SMA (IPA), SMA (IPS), SMA (Catholic), SMA (protestant), MA (Language), MA (IPA), MA. (IPS), MA (religious), SMK, Senior High School Equivalency/Paket C (IPS), and Junior High School Equivalency/Paket B.

4) List of regional and educational units scores: The features contained in the list of regional values and educational units include: levels (SMP/MTs, SMA/MA, SMK, Junior High School Equivalency/Paket B, Senior High School Equivalency/Paket C), test modes (all, UNBK, UNKP), analysis units, city/district, year, education unit, education unit status (public, private, public and private), level, education unit status (public, private, public and private), type of education unit, study program, and exam subjects, graphics, tested indicators, and scores. An example of displaying a list of regional and educational units' scores is presented in Figure 5 below.

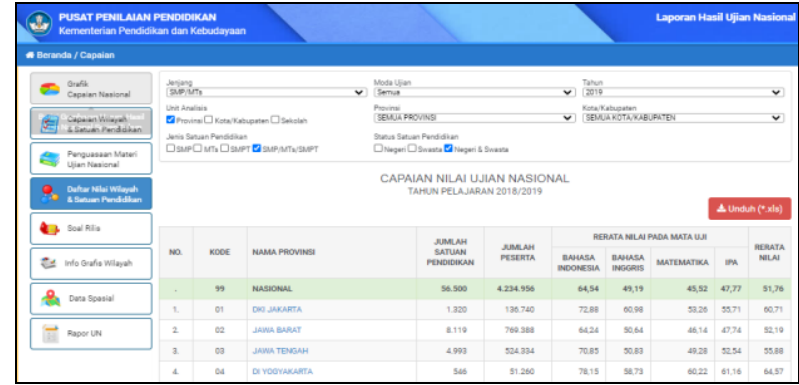

Fig. 5. List of regional national exam education units SMP/MTs for the 2018/2019 academic year.

From Figure 5, the information displayed can be seen in the form of graphics, statistics, and the distribution of the average UN score achievement of each subject tested based on education level.

5) Released questions: The features contained in the UN release questions include several sample questions from the several subjects tested.

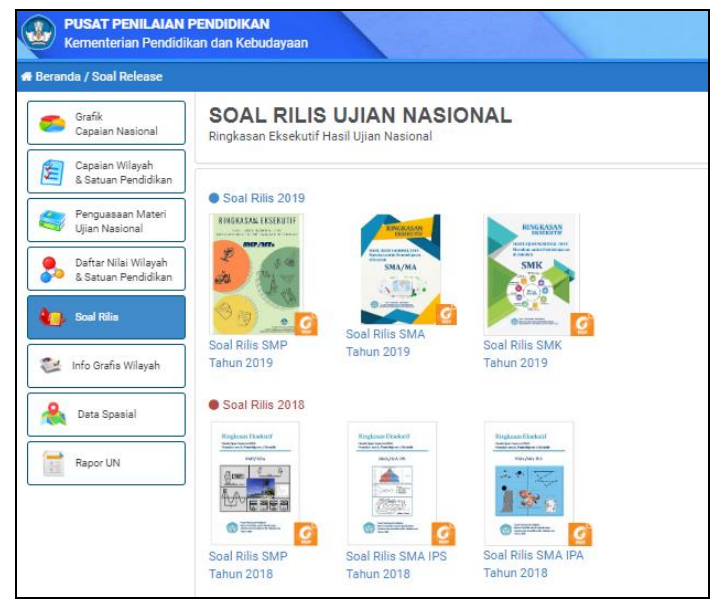

Fig. 6. Examples of national examination questions released in the 2018/2019 academic year.

From Figure 6, the information displayed is an example of questions followed by discussion of how to answer them, available for SMP, SMA, and SMK levels.

6) Regional infographic: The features contained in the Regional Infographic display the diagnosis of the 2019 National Exam Results. The results presented include statistics of city/district and provincial scores for each level of education. 


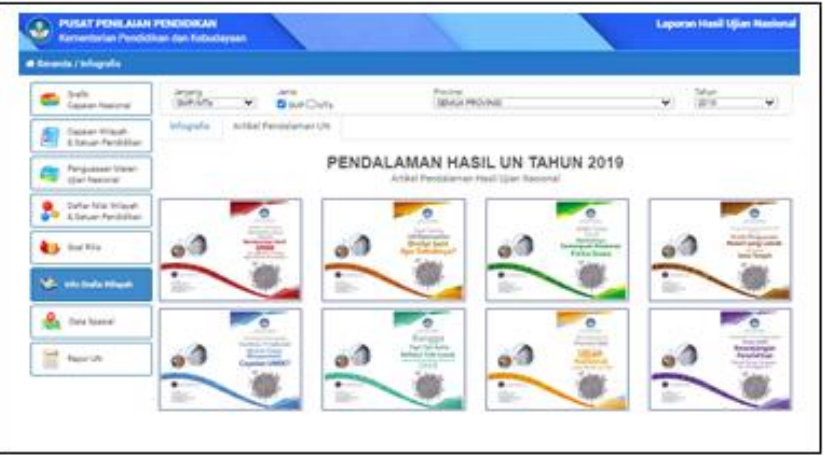

Fig. 7. National examination results as feedback to regions in the $2018 / 2019$ national examination.

In Figure 7, the information displayed is the statistical results and comparison of UNBK and UNKP scores, available for SMP, SMA, and SMK levels.

7) National examination result spatial data: The features contained in the spatial data of the UN results include levels (SMP / MTs, SMA / MA, SMK, Senior High School Equivalency/Paket $\mathrm{C}$, and Junior High School Equivalency/Paket B), year, test mode (all, UNBK, UNKP), zone, region (national, provincial), city/ditrict, exam subjects, and level (level 1. knowledge and understanding, level 2. application, level 3. reasoning) year, education unit, education unit status (public, private, public and private), and level.

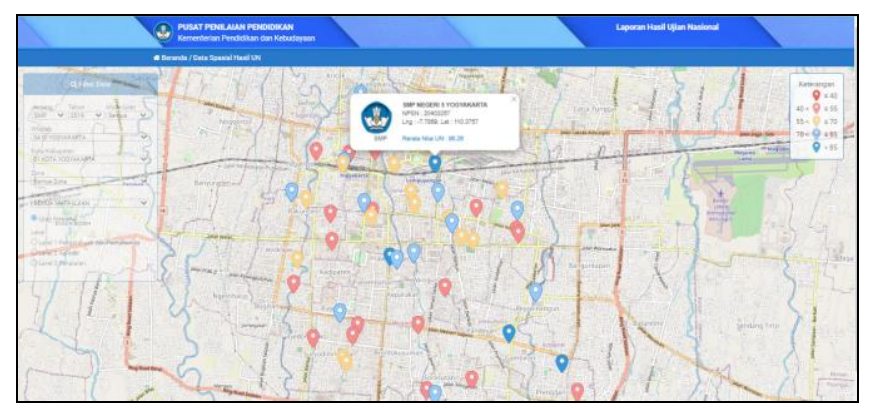

Fig. 8. Spatial data in the form of school location maps for the 2019 national examination.

From Figure 8, the information displayed is the result of analysis by displaying the location of schools in a certain area.

National examination report card: The features contained in the national examination report include: diagnosis of national exam results, trend of National Examination in last two years, general statistics, distribution of scores, schools with a score percentage $\leq 55$, material achievements, level (SMP/MTs, SMA/MA, SMK, Senior High School Equivalency/Paket C, and Junior High School Equivalency/Paket B), Examination mode (all, UNBK, UNKP), province, city / district, year, Education Unit, Education Unit Status (State, Private, Public and Private), Level (major), and Education Unit Status (State , Private, public and private), type of education unit, relation code, test subjects, graphics, statistics, and distribution of average national examination scores.

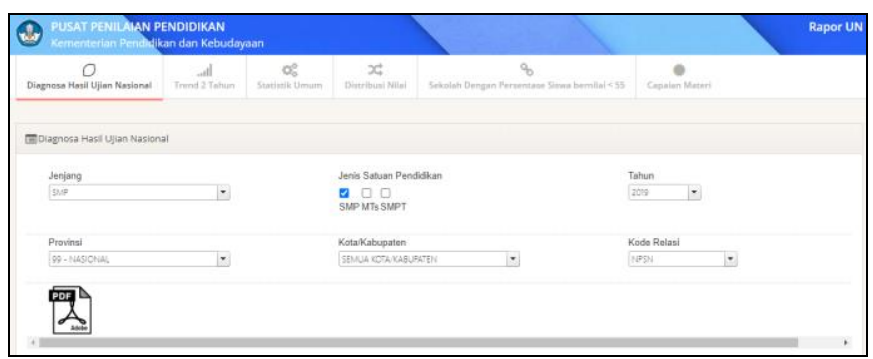

Fig. 9. Data for national examination results with various analysis variants in the 2019 national examination.

From Figure 9, the information displayed is remarkable and accurate from various analysis results that can make it easier for stakeholders to improve education. The quality of information is very important for decision making [18]. Quality information can be produced by the existence of a database that supports accurate data processing. All information on the results of the National Examination report is easily accessible in the website. The advantages of website applications, namely: easy to develop, easy to access, easy server setup, easy to distribute information, and flexible [19].

\section{CONCLUSION}

The results of this development is in the form of a National Assessment Report Data Analysis application (ANDALAN) in accordance with the user's design with the output of two types of reports, namely: student UN scores and national UN results reports.

\section{REFERENCES}

[1] A.R. Wulan, A. Isnaeni and R. Solihat, "Penggunaan Asesmen Elektronik Berbasis Edmodo Sebagai Assessment for Learning Keterampilan Abad 21," Indonesian Journal of Educational Assessment, vol, 2, no. 1, 2018.

[2] E.Y. Wijaya, D.A. Sudjimat, A. Nyoto and U.N. Malang, "Transformasi pendidikan abad 21 sebagai tuntutan pengembangan sumber daya manusia di era global," Prosiding Seminar Nasional Pendidikan Matematika, vol. 1, no. 26, pp. 263-278, 2016.

[3] Trianto, Mendesain Model Pembelajaran Inovatif-Progresif. Jakarta: Kencana, 2009.

[4] S.D. Cahyo, A.B. Al Fariz and C.A. Lestari, "Does Internet Usage Frequency Give Impact To Student's Academic Performance?" Indonesian Journal of Educational Assessment, vol. 3, no. 1, 2020.

[5] BSNP, Prosedur Operasional Standar (POS) Penyelenggaraan Ujian Nasional Tahun Pelajaran 2015/2016, 2015.

[6] BSNP, Prosedur Operasional Standar (POS) Penyelenggaraan Ujian Nasional Tahun Pelajaran 2016/2017, 2016.

[7] BSNP, Prosedur Operasional Standar (POS) Penyelenggaraan Ujian Nasional Tahun Pelajaran 2017/2018, 2017.

[8] BSNP, Prosedur Operasional Standar (POS) Penyelenggaraan Ujian Nasional Tahun Pelajaran 2018/2019, 2018.

[9] L.J. Cronbach, Essentialof Psychological Testing, 3th ed. New York: Harper \& Row, 1960.

[10] N.E. Gronlund and D.R.L. Linn, Measurement and assessment in teaching. New York: Macmillan Publishing Company, 1990. 
[11] L. Crocker and J. Algina, Introduction to classical and modern test theory. Holt, Rinehart and Winston, 6277 Sea Harbor Drive, Orlando, FL 32887, 1986.

[12] R.L. Brenan, Educational Measurement. Washington: American Council on Education Praeger, 2006.

[13] W.A. Mehrens and I.J. Lehman, Measurment and Evaluation in Educational and Psychology. New York: Holt, Rincchart and Winston, Inc, 1991

[14] A. Anastasi and S. Urbina, Psychological Testing 6th. New York: Macmillan Publishing Company, 1988.

[15] H. Indriana, P. Feddy Setio, F. Rahmawati, F. Silmi E.P. Adhistya and W.S. Filemon, "Development of Learning Strategy Recommendation System to Train Metacognition and Self-Regulated Learning in Algorithm and Data Structure Course," 2nd International Conference on Educational Assessment and Policy (ICEAP 2019), pp. 212-218, 2019.
[16] H. Hilman, Perbedaan Aplikasi Berbasis Web, Aplikasi Berbasis Desktop, dan Aplikasi Berbasis Mobile [Online]. Retrieved from: https://www.plimbi.com/article/166177/aplikasi-berbasis-web--desktopdan-mobile, 2016.

[17] Z. Arifin, Perbedaan Aplikasi Berbasis WEB dan DESKTOP [Online]. Retrieved from: https://www.zainularifin.com/2015/05/03/perbedaanaplikasi-berbasis-web-dan-desktop/, 2015.

[18] C. Huda, Perkembangan Pengolahan Data. Computer Science BINA NUSANTARA Institute of Creative Technology University Malang [Online]. Retreived from: https://binus.ac.id/malang/2017/09/perkembangan-pengolahan-data/, 2017.

[19] A. Muharam, 5 Keunggulan Aplikasi Web yang Harus Anda Ketahui [Online].

Retrieved from: https://www.logique.co.id/blog/2018/07/27/keunggulan-aplikasi-web/, 2018 